\title{
ISSUES AROUND VOCATIONAL AND CAREER COUNSELLING IN NIGERIA
}

\author{
Moromoke Nimota Raji* http://orcid.org/0000-0002-7615-2962
}

\begin{abstract}
Background. Using the second University as benchmark, this paper undertakes a comparative analysis of the curriculums in Guidance and Counselling of the University of Ibadan (Nigeria) and that of the University of Applied Labour Studies, Mannheim in Germany.
\end{abstract}

Research aims. The ultimate aim is to determine the adequacy or otherwise of the undergraduate syllabuses in career counselling in Nigerian Universities.

Methodology. Methodology includes visits to both Universities to collect relevant data. Interview was conducted with a selection of staff and students of the University of Ibadan while field investigations were carried out in a selection of secondary schools in South Western Nigeria.

Key findings. Analysis reveals that the programme of study in the selected Nigerian University is somewhat inadequate, and this is found to be affecting the practice of career counselling in secondary schools. A revision of the programme in Ibadan University is recommended, and also an improvement in the quality of scientific research by specialist academics in the area.

Keywords: vocational and career counselling, benchmark, curriculums, modern guidance and counselling

JEL Codes: 015, J24

\section{INTRODUCTION}

This paper compares the study programme of the Hochschule der Bundesagentur für Arbeit, (HdBA) Mannheim, Germany and that of the University of Ibadan (UI), Nigeria. It takes off with the assumption that the one of Hochschule der Bundesagentur für Arbeit represents

\footnotetext{
* Department of Arts and Social Science, College of Education, Ipetu-Ijesa Campus, Osun State University, Nigeria.
} 
a standard undergraduate programme for Career Counselling and it is therefore against it that the one of the University of Ibadan is being measured. In the course of researching for the paper, the author collected rare texts through which she obtained information on how the discipline started originally. It also studied and analysed closely the handbook of the programme of the University of Ibadan, visited the Department and carried out an inspection of the equipment and resources which the institution possesses in the area. Finally, the researcher also interacted with, and interviewed, a number of students and staff in the Department. To take a measure of the effectiveness or otherwise of the programme, she visited a number of secondary schools (junior and senior), administering questionnaires on some of the pupils with the aim of finding out whether they were guided by the advice of their vocational and career guidance specialists while selecting their subject combinations. In the end, what the paper discovers about the Nigerian programme is somewhat unsalutary.

The syllabus for example is considered to be in need of considerable revision, the facilities and resources inadequate and the morale and motivations of staff, low. All these portend great ramifications for competence, performance and quality of delivery of the products of the institutions in question. Before commencing the analysis, the paper undertakes a brief review of the development of Guidance and Counselling as a professional discipline in Nigeria, tracing it to the time the first-degree programme in the field took off at the University of Ibadan.

\section{SHORT HISTORY OF MODERN GUIDANCE AND COUNSELLING IN NIGERIA}

As a field of study, "Guidance and Counselling" was first introduced in Nigerian Universities in the 1980s. It started off at the Universities of Ibadan, Lagos and Ife. Over the years however, the discipline was also introduced in other Nigerian Universities. Oladele (2007) traces the history of formal/modern vocational counselling in Nigeria from 1950 to 1981. According to him, formal vocational counselling started as a helping hand for the graduates of St. Theresa College, Oke-Ado, Ibadan. Some Rev. Sisters were then invited to counsel sixty female students who had just completed their college certificate requirements. 
These girls were counselled on the need for proper job selection and placement in 1956. The Rev. Sisters did not stop giving their services with St. Theresa College, but followed up their activities in other schools in Ibadan and its environment. The activity took a new turn in October 1961 when principals of post-primary schools and the representatives from Ministries of Education, Health, Trade and Industry and Labour initiated and inaugurated the "Ibadan Career Counsellors" in October 1961. This is how the association known as the Nigerian Careers Council was born. Berepiki was nominated by the Federal Ministry of Education as its first chairman, and the Council would soon go ahead to launch a journal known as "The Career".

From that year on, more bodies at federal schools began to associate with the activities of the council. Members of this council arrange vocational talks and interviews for school pupils. They rendered services that made the pupils to have clear knowledge of their strengths and weaknesses, likes and dislikes, special aptitudes and the training required for particular careers. As the activities of this group continued to yield positive results, it attracted the attention of other relevant bodies. 1975 was the year when the first Department of Guidance and Counselling in Nigeria took off. This was at the University of Ibadan and the development later led to the formation of the Counselling Association of Nigeria (CAN) in 1976 at the same University of Ibadan. Olumakinde was the first president of the Association.

As the importance of a career counsellor in secondary schools became clearer and clearer, the Federal Government included a clause in the 1980 edition of the National Policy on Education, making it mandatory for every school to have a career counsellor viz:

In view of the apparent ignorance of many young people about career prospects, and in view of personality maladjustment among school children, career officers and counsellors shall be appointed in post-primary institutions (1998, p. 41).

It was following this that other Universities in the country began to introduce programmes in Guidance and Counselling at the undergraduate levels. Clearly, the main aim of introducing Guidance and Counselling programmes in higher institutions in Nigeria is that of training professional vocational and career counsellors who would in turn guide secondary school pupils on the choice of life-long careers. 
Paragraph 81 of the newly reviewed National Policy on Education (2013) went a step further and considered offering Career Counselling to University students, viz:

Provide high quality Career Counselling and lifelong learning programmes that prepare students with the knowledge and skills for self-reliance and the world of work (2013, p. 35).

The said policy also lays emphasis on the need for continuous training of teachers in general guidance and counselling concepts as well as in establishment and equipping counselling clinic in schools to afford effective delivery of Vocational and Career Guidance and the General Guidance/Counselling Services:

vi) Guidance and Counselling:

Government shall continue to make provision for the training of the teachers in Guidance and Counselling;

Establish and equip:

Counselling Clinics,

Career Resource Centres,

Information Centres.

Proprietors of schools shall provide adequate number of guidance counsellors for their institution.

vii) Voluntary Counselling and Testing (VCT) Referral Service.

viii) Providing care and support for those infected and affected by HIV/ AIDS [...] (National Policy on Education, 2013, p. 35).

Unfortunately, the intention which gave birth to the introduction of the programme of vocational and career guidance has almost been totally forgotten. As at 2016, the services of a vocational counsellor have become almost totally neglected in most public schools in Nigeria.

Most young adolescents now select their subject combination without professional guidance from Vocational Counsellors. The issues of talents, flairs and/or strengths and weaknesses, are no longer taken into consideration before decisions are taken by most students/adolescents on their subject combination. Most adolescents determine their subject combination either on the basis of their parents' career and the success that they have recorded through it, peer group influence or perceived prospects of such careers. The consequence of this is the high rate of drop-out and exam-malpractices in schools and higher 
institutions. The analyses carried out by the author on the quality of training/learning at the nine technical colleges in the State of Osun in 2014 and 2015 confirmed this assertion (Raji, 2012, 2014, 2015). This situation calls for reactivation of professional services of Vocational and Career Counselling in Nigerian schools.

\section{INDIGENOUS FORMS OF COUNSELLING IN NIGERIA}

Guidance and Counselling has always been part of Nigeria's culture. Traditional systems of counselling have existed long before modern methods were introduced to Nigeria in 1958. Even till date, traditional counsellors (Traditional Rulers - Emirs in Hausa land, Obas in Yoruba land, Obis in Igbo land and chiefs at the village levels, parents, household elders in an extended family system, peer groups and youth associations, religious leaders, the traditional priests, etc.) continue to represent a strong force in the business of traditional guidance and counselling. Their practices extend to all areas of counselling (marital, Vocational and Career, Criminology, among others) of the modern guidance/counselling. Up till date, many Nigerians still prefer consulting the Babalowos, the Pastor, Imam or the elders in their community when they are confronted with problems on their professional, marital, financial, or spiritual life. This is in spite of the fact that and, according to Olu-Makinde (1998), these indigenous African Counsellors are not recognized in the dictionary of modern western counselling practices. As the mention author claims, the traditional counsellor is regarded or labelled as a herbalist, a diviner, or at best an advice giver, because of the belief that his/her counselling approach and technique are not scientific. Nonetheless, these "unorthodox und unscientific" stakeholders remain a force to be reckoned with if any meaningful professional progress has to be achieved in the field of modern counselling in Nigeria, especially in the efforts aimed at achieving world standard vocational and career counselling. It is the view of this author that a good networking relationship should be encouraged between the traditional and modern stakeholders in counselling practices. 


\subsection{Career choice and the stakeholders involved in the processes}

Nigerian scholars such as Onoyase and Onoyase (2009), Oladele (2007), as well as Raji (2012) have in their works continued to emphasize the need to consider the following factors in the efforts to achieve wise vocational and career decision:

- social and socio-demographic characteristics (gender, health, history, employment of parents, household size, individual life experience),

- needs and interests of young people and their parents,

- opportunities in the labour market and development opportunities for the selected profile,

- development opportunities (in the sense of training) for the desired professional choice,

- thorough knowledge of interests, abilities, needs and values and development of positive work attitude,

- increase in students' knowledge of career possibilities, the structure of the world of work and job duties and requirements,

- know-how on principles of decision-making and planning skills.

The above stated factors can only be achieved if full time professional vocational and career counsellors are employed in educational institutions in Nigeria and the world at large. Organizations and individuals like OECD (2004), Deutscher Verband für Bildung und Berufsberatung (dvb) (2007) and individual authors like Schiersmann and Weber (2013), Weiß (2009), Ertelt (2007), among others have expressed very similar opinions on what is required in order to be able to guide youths in the process of makingwise career decisions. What the investigations conducted by the author during her dissertation research field work in 2009 and situation analysis of the nine Technical Colleges in Osun State in 2014 and 2015 respectively, demonstrate that about $90 \%$ of young people have no knowledge of, and have not been guided to take cognisance of the above-mentioned factors before selecting their subject combination while in secondary schools. They lack opportunities for a professional vocational and career guidance during their transitions from Junior Secondary School to Senior School in Nigeria. Most young people selected their subject combinations and future career on the basis of factors such as peer group influence, 
parental influence, societal value, "fantasy" information from social media, etc. The important factors that are paramount to making good career decisions were hardly considered.

As a result of wrong subject combinations and wrong career decisions, the number of school and study drop-outs has continued to increase year after year. This has naturally led to high rates of criminal activities in Nigeria. This has in no small measure contributed to economic difficulty and at the same time caused problems for affected individuals, their families and the society at large. It should be considered as an urgent matter to make sure that young people decide their future career after junior secondary school through the professional guidance of the vocational and career counsellor. In Nigerian secondary schools three profiles of choice are available after the junior secondary education:

- science (science oriented subjectcombinations),

- arts (humanities oriented subject combinations),

- social science (vocational and business oriented subject combinations).

In a research carried out by Onoyase and Onoyase (2009) and which focused on the relationship between personality types and career choice of students of secondary school in the Federal Government Colleges (in Anambra state), findings have shown that students chose the following career after junior secondary school focuses only on the basis of whether the career can win them great prestige in the future. They further presented the following as the choices of the targeted adolescent:

- medicine,

- accounting,

- law,

- pharmacy and

- engineering.

Onoyase and Onoyase (2009, p. 114) came to the conclusion that the targeted adolescents were both ignorant of subject combinations that could lead to their dream career and as well as those careers that suittheir personality types.

Not only should adolescents be well guided in the process of making career choices, parents and teachers also need to be educated on the important factors. Furthermore, professional vocational and career guidance/counsellor also need to work as a team with community leaders, politicians, philanthropists from diverse career background etc., to access necessary supports to facilitate quality vocational and 
career counselling programme in Nigerian schools and the world at large.

Enechet et al. (2008, p. 31) took an initiative from the new national policy on education and suggested that the services of a school counsellor ought to begin from the first year of secondary school education to the end of senior secondary school. A file is to be opened on each student for the purpose of recording data on aptitudes, performance in class and examination, temperament, interests, family background, etc. At the appropriate time, the data, as well as the results of the state examination at the end of junior secondary education would be used in the process of advising the student on the subject combination, he/ she should opt for. Also, to be involved in the process are the parents and class teacher of the adolescent.

\subsection{Expected services of vocational and career guidance and counselling}

Important points extrapolated from the "Internationale Vereinigung für Schul- und Berufsberatung" (IVSBB) on the expected services of vocational and career counselling are presented as follows:

- High quality vocational and career counselling services should have life-long impact on the subject.

- It must provide professional guidance to every individual by making all relevant information that could be needed to achieve wise career decision making available.

- The intervention from vocational and career counselling/guidance should guarantee continuous career development in terms of continuous educational development and career progress.

- Vocational and career counselling is a profession that recognises the importance of giving equal educational and job opportunities to every person, regardless of their social demographic status or background.

- And to achieve these equal opportunities for all, there must be continuous assistance from professional vocational and career counsellor.

OECD (2004) presented its view on the expected activities, services and medium of service delivery in vocational and career guidance/ counselling. Summaries of these are in the graphic below. 


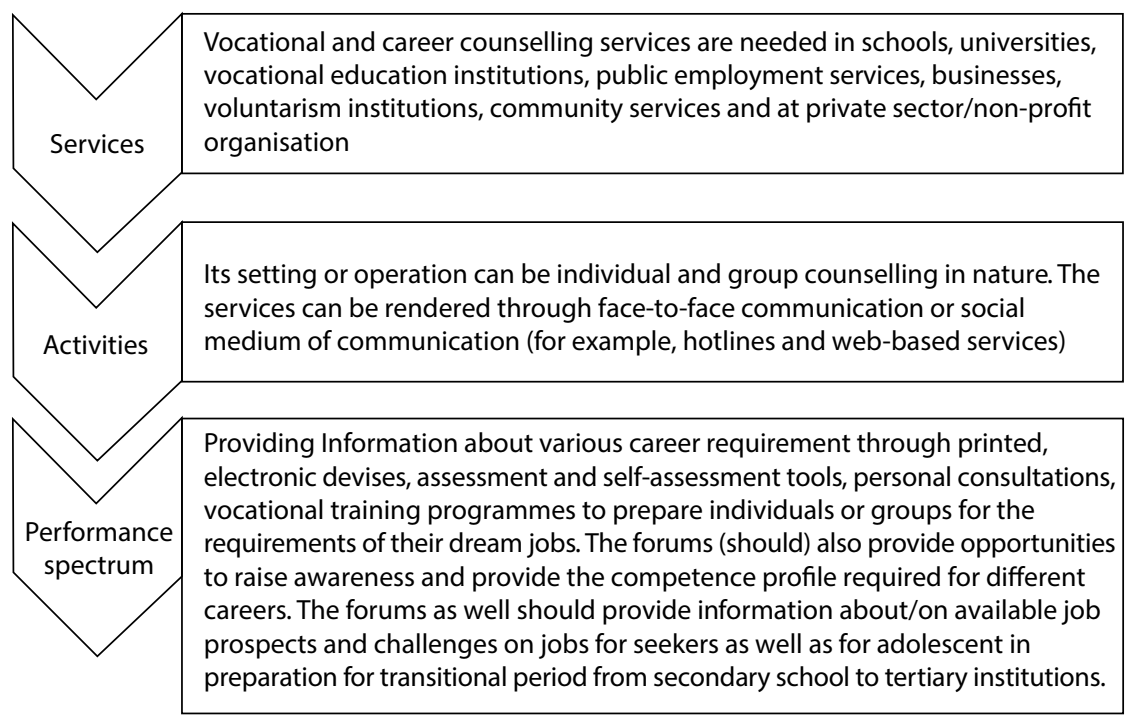

Figure 1. Activities and services of vocational and career guidance as presented in the manual for political responsible

Source: based on OECD, 2004, p. 12.

\section{COMPARATIVE ANALYSIS OF PROGRAMS OF STUDY AND IMPLEMENTATION CRITERIA - NIGERIA AND GERMAN UNIVERSITIES AS BENCHMARK}

In undertaking a comparative analysis of the Vocational and Career Counselling programmes of the University of Ibadan and that of Hochschule der Bundesagentur für Arbeit (HdBA), Mannheim, it is necessary to make it clear that this author holds the view that the programme of the latter institution represents the standard against which that of the former is being measured. In other words, HdBA's Counselling curriculum stands as a benchmark with which to gauge any undergraduate syllabus in Guidance and Counselling.

To be sure, efforts have been made by major Nigerian scholars like Olu-Makinde (1998), Agbaje and Agbaje (2014) and Oladele (2007) at ensuring a professionalized Vocational/Career Counselling in Nigeria, and this cannot be over-emphasised. Partly inspired by their pioneering efforts, the author of this paper also carried out the analysis of the Guidance and Counselling programme of the University Ibadan in 
2007 and 2009. Group interviews were conducted with Guidance and Counselling students and four lecturers of the University of Ibadan in 2007. In 2009 the fact-finding intention was extended to Obafemi Awolowo University and Lagos State University (Raji, 2007, 2012). Issues taken into consideration in comparing the two programmes in question include: (i) content of syllabus with the theoretical and practical components of the two programmes set side-by-side each other, (ii) organization and methods of delivery of the programme, (iii) material and financial resources available for the implementation of the respective syllabus and (iv) opportunities for further exposure and programme exchange.

\subsection{The syllabus}

The Undergraduate Academic Programme Handbook (2006), of the Department of Guidance and Counselling, University of Ibadan, Nigeria contains theories of counselling like the Need-Drive-Theory and Trait-and-Factor-Theory. The syllabus contains concepts in developmental psychology, adolescent psychology, deep psychological and sociological concepts that serve as guidelines for decision making. It was noted as well that there were enough theoretical concepts on counselling techniques and approaches in the analysed handbook of Program of Guidance and Counselling, University of Ibadan (2006). The limitation of the programme was observed in the organization and practice of Vocational and Career guidance, especially as it obtained in the programme of study at the selected University in Germany with which it was compared, and some works of Europeans authors.

What obtained in Nigeria content was not sufficient to really prepare students in training at the undergraduate level for the challenges awaiting them in the practice of a profession of Vocational and Career counselling. Organizations like CEDEFOP (2004), OECD (2004), Deutscher Verband für Bildung und Berufsberatung (dvb) (2007) and individual authors like Schiersmann and Weber (2013), Weiß (2009), Ertelt (2007), among others, share the same opinion about the need to improve on the standard of Vocational and Career Counselling and they have been working conscientiously to put Vocational and Career Counselling on a professional track in EU countries.

According to Ertelt (2007), the European Union has laid down quality criteria for the development of an internationally recognized 
curriculum in Vocational and Career Counselling. A "Model Curriculum" for the field of Vocational and Career Counselling was also designed by the same author in line with internationally recognized competence profile for vocational and career counsellors in Europe. His designed curriculum is called: "Mindestmodulefür das Kerncurriculum eines Studiengang für Berufsberatung auf der Grundlage von Kompetenzbereichen" (Ertelt, 2007).

Schiersmann in 2006 developed a Master Syllabus for Vocational Counselling and was at Ruprecht-Karls-Universität Heidelberg same year. The principle guiding the syllabus is in line with the international competence profile for the practice of Vocational and Career Counselling in Europe was, in fact also presented in Master Syllabus. The Syllabus has since been introduced at the Ruprecht-Karls-Universität Heidelberg. Schiersmann and her team later reviewed the syllabus so as to make it align with current demands in vocational counselling (Ertelt, 2010).

The University of Applied Labour Studies (HdBA), Mannheim started a degree programme on Vocational Counselling in 1972 and engaged year in year out in continuous revision of the said program so as to meet with international standards. The following represents the outline of courses at the HdBA in 2012:

- Professional and Industrial Engineering and Ergonomics (Berufsund Arbeitswissenschaften),

- Case Management (Fallmanagement),

- Group Counselling Processes (Gruppenprozesse),

- Vocational and Adult Education Systems (Systeme der beruflichen Aus- und Weiterbildung),

- Vocational and Career Aptitude Diagnosis (Berufliche Eignungsdiagnostik),

- Employment Rights, Promotion and Social Security (Arbeitsförderungsrecht, Soziale Sicherung),

- Labour, Economic and Social Rights (Arbeits-, Wirtschafts- und Sozialrecht) (HdBA in 2012).

Oladele (2007, p.133) gave the following as the outline of courses at the University of Ibadan:

- social, Philosophical and Psychological principles underlying guidance and other pupil personnel services,

- history and development of Guidance and Counselling, 
- the nature and range of human characteristics and methods of measuring them by individual appraisal based on continuous assessment method,

- the principles and practice of psychometric testing, their use in guidance and counselling,

- vocational development theory,

- educational and occupational information,

- counselling theory and practice,

- professional relationships and ethics,

- administration and co-ordination of guidance programs,

- supervised counselling practice-practicum.

Similar concepts were discovered in the University's Handbook of 2006. Other important issues on the programmes of the two Universities are captured in Table 1.

Table 1. Summary of Study programs of Hochschule der Bundesagentur für Arbeit (HdBA), Mannheim and University of Ibadan (UI)

\begin{tabular}{|c|c|c|}
\hline \multicolumn{2}{|c|}{ Hochschuleder Bundesagentur für Arbeit, Mannheim } & University of Ibadan \\
\hline Degree & Bachelor of Arts (B.A.) & $\begin{array}{l}\text { Bachelor of Education } \\
\text { (B. Edu.) }\end{array}$ \\
\hline $\begin{array}{l}\text { Duration of } \\
\text { Study }\end{array}$ & $\begin{array}{l}3 \text { Years (5 Semesters) } \\
\text { Students are admitted into the University } \\
\text { after A Levels (i.e. eight years of high } \\
\text { school) }\end{array}$ & $\begin{array}{l}4 \text { Years (8 Semester) } \\
\text { Students admitted after } \\
\text { six years of high school }\end{array}$ \\
\hline $\begin{array}{l}\text { Form/Terms } \\
\text { of Study }\end{array}$ & Full time & Full time \\
\hline $\begin{array}{l}\text { Number, } \\
\text { Duration } \\
\text { and Focus of } \\
\text { practical }\end{array}$ & $\begin{array}{l}4 \text { practical exercises, each for } 4 \text { months, } \\
3 \text { of the practical focus on gaining practi- } \\
\text { cal experience in Vocational Counselling } \\
\text { and } 4^{\text {th }} \text { for Bachelor-Thesis }\end{array}$ & $\begin{array}{l}2 \text { practical exercises, } \\
\text { each for } 6 \text { weeks and } \\
\text { focus is to gain practical } \\
\text { experience in teaching } \\
\text { and counselling }\end{array}$ \\
\hline $\begin{array}{l}\text { Place of Prac- } \\
\text { tical exercise/ } \\
\text { Internships }\end{array}$ & $\begin{array}{c}\text { Public employment services (PES), Job- } \\
\text { centres, Career Services in Schools and } \\
\text { HEI (national and international) Ministry } \\
\text { of Work }\end{array}$ & Secondary School \\
\hline $\begin{array}{l}\text { Method and } \\
\text { Organisation } \\
\text { of teaching/ } \\
\text { learning } \\
\text { process }\end{array}$ & $\begin{array}{c}\text { Modes of Teaching consists of Seminars, } \\
\text { Excursions, Power-Point-Presentations, } \\
\text { Micro-Counselling, etc. }\end{array}$ & $\begin{array}{l}\text { Relatively Classical } \\
\text { Methods of teaching } \\
\text { comprising mainly of } \\
\text { lectures }\end{array}$ \\
\hline Credit Points & 180 credits minimum & 120 credits minimum \\
\hline
\end{tabular}

Source: Extract from self report HdBA, 2011, p. 34 ff., and UI, self report 2006, p. 2 ff. 
As can be seen in Table 1, the programmes both at HdBA and the University of Ibadan share a number of things in common. While however, that of the University of Ibadan focuses on Guidance and Counselling as a general area of specialization at the first-degree level, that of HdBA lays more emphasis on Vocational Counselling. Also, while University of Ibadan seems to be strong on the theoretical, HdBA stresses, on the other hand, the processes of instilling practical counselling skills. For example, courses in Case Management and Group Counselling Processes. Finally, the fact that HdBA is bold on courses having to do with the rights of workers, social rights, social security and the influence of the working environment and facilities on workers' productivity and morale.

Also, Table 1 shows that HdBA has four mandatory practicals worked into the programme with three of them geared towards gaining concrete experience in Vocational Counselling. In Ibadan, there are only two practical aspects, each lasting six weeks and with both of them carried out in secondary schools where the students end up as classroom teachers. The supervision of student counsellors seems also to be taken more seriously in HdBA than in Ibadan.

There are other issues that are not overtly visible in either of the two outlines or in Table 1. They are discussed under four headings, as follows:

- the structure of the syllabus - content and implementation,

- organization and methods of teaching,

- material and financial support put in place for the proper implementation of the content of the syllabus of study,

- exchange programme for lecturers and students.

\subsection{Structure of both countries syllabus - content and implementation}

The focus here is on how much of the content of undergraduate syllabus of the compared undergraduate programme of guidance and counselling of University of Ibadan features expected competence and skill need to be acquired by students that would prepare them for the professional job of a Vocational and Career Counsellor. It was observed since 2009 till date that the undergraduate syllabus at the Universities of Ibadan is relatively dominated with generally psychological theories (Oladele, 2007, p. 133). Less attention is given 
to theories and practice of Vocational and Career Counselling. During the teaching-learning-process, the contents of these theories are often dictated to students with little or no attention paid to the issue of how to apply them in diverse cultural backgrounds in Nigeria. In contrast, Mannheim seems to regularly update the content of its syllabus (theories and praxis) which is in line with current demand in the world of work and the professional practice of Vocational and Career Counselling. Indeed, the Hochschule der Agentur für Arbeit, Manheim, Studienführer (2010), contained new theories of social communication from Watzlawick, Rogers, Schulz originally from Thun and that of conflict management from Glasl. Ertelt and Schulz (2015) carried out an extensive analysis of Ivey, D'Andrea, Bradford-Ivey and Simek-Morgan (2002), "drei Kräfte der Beratung" and methodically gave suggestions on how to apply the theory in the current Vocational and Career Counselling practice in Europe. In the book more theories were analysed and the possibility of their applicability in-line with current demands in Vocational and Career Counselling were presented.

Be that as it may, there are current efforts being made to update the syllabus in Nigerian Universities. This new effort is commendable. It is the view of the paper that there is the need to ensure that the process of revision is comprehensive and thorough such that graduates of Nigerian Universities will be able to compete favourably with those from Universities elsewhere, but more especially from the Western world. One other point that needs to be made is that the syllabus of HdBA seems to make more provision for practical training. The programme has four practical opportunities for students; each for four months and this is often well coordinated, supported, supervised and evaluated by the Professors of the institution and experienced workers from relevant Ministries.

In contrast, in the University of Ibadan, the students have two practical exercises, each for 6 weeks, with both restricted to secondary schools where many stakeholders in the school system hardly give the counsellor students the opportunity or an enabling environment that could afford the chance to be exposed the practical knowledge, they would need for their future job demands. Given this situation, it is not often possible to ascertain that students actually have even the minimum practical experience they require for their competence as future guidance counsellors. Students who undertake their practicals in secondary schools are automatically turned into class teachers 
with little or no opportunity given to the practice of "Guidance and Counselling." This is an area that really requires a lot of attention in the process of curriculum review in Nigerian Universities.

\subsection{Organization and methods of teaching}

The implementation of the syllabus requires combination of up-to-date methods of teaching and complementary programme like seminars, workshops, excursions, lecturing, group discussions, power-point-presentations among other. As at 2009, in University of Ibadan, it was observed that the training method is still largely that of the old, traditional chalk and blackboard and/or whiteboard and marker. In most cases, lecturers simply dictate notes to their students while audio-visual facilities that are crucial for practical training (micro-counselling) are rarely available. And where and when they are, the facilities are outdated or are no longer functioning. The use of new media is very minimal while most recommended publications that can be considered as recent are those of lecturers teaching different courses. Available counselling clinics seem to be poorly-equipped, and in most situations the equipment is very old. A visit was made to HdBA in 2009, 2010 and 2013 and was able to participate in the micro-counselling process. The counselling room was fully equipped with modern equipment like video-camera, video-tape, reflection-board, TV sets, among others. These facilities provide the students the opportunity to have appropriate feedback after sessions of micro-counselling and they were able to reflect on their inadequacies and short-comings and got suggestions on how to improve on their practical ability. The students of these institutions also benefit from opportunities of exchange programme with other European countries. Since returning to Nigeria in 2013, and as earlier stated, it was observed that things have also begun to improve in Universities here.

Increasingly, lecturers are beginning to make use of audio-visual facilities like overhead projectors during the period of lesson delivery. Lecturers also make efforts on their own to win fellowships and grants which consequently enable them to travel outof the country and participate in exchange programmes. These, in turn, have had positive effects on their performances in their primary assignments. The only problem that the writer perceives in this situation is that the changes seem to be due to individual efforts and innovations, whereas 
what is needed is a kind of systemic overhaul of the approaches to, and methods of, teaching.

\subsection{Material and financial support for the proper implementation of the content of the syllabus}

At the University of Ibadan, it was observed that the funds made available for the running of the counselling programme at the period of the field research is very limited. Relevant and current literatures that are needed for academic work by students are lacking in the library. Internet facilities are also very limited. The result of interviews conducted at the Institution in 2009 and 2012 respectively showed that lack of regular power supply make things worse, the implication being that on occasions when a lecturer succeeds in laying his/her hands on audio visual equipment, availability of electricity with which to power it cannot be guaranteed. Again, this situation contrasts sharply with what obtains in the German context. The study revealed that beside the fact that enough support is provided for the running of the programme, financial supports are also given to students during their practical exercise. The library is well equipped with current literatures and computers are connected to internet both at the institute level and in the library for effective research. Again, I hasten to add that the situation in the local context has improved considerably. Increasingly, the problem with internet access is getting resolved and availability of generators powered by fossil fuel has also led to significant improvement in electricity supply.

\subsection{Exchange programme for lecturers and students}

Lecturers and students of the selected Nigerian University have limited opportunity for national and international collaboration. During the interviews conducted in 2009, only two out of the six lecturers interviewed have heard opportunities to attend international conferences and workshops in Europe and other advance countries of the world whether once in a while or on a fairly regular basis. The Counselling Association of Nigeria organizes conferences on a yearly basis, but only three out of six interviewed lecturers of the Department indicated that they participate regularly in some of the workshops and conferences. None of the students interviewed has had an opportunity for an exchange 
programme either nationally or internationally. The HdBA on the other hand has good collaborative project with other EU-Nations for students and lecturers. For instance, HdBA has academic partnership with some institutions in Poland.

\section{Recommendations for the Nigerian University}

Based on the comparative analysis of the study programme of Guidance and Counselling of the two selected Universities carried out above, certain weaknesses have been identified in the current syllabuses of the Nigerian institution. It is against this fact that the following suggestions are being proffered for an improvement in the curriculum and services of Vocational and Career Counselling in Nigeria.

- Input and inspirations from indigenous practices and methods of counselling

The Nigerian syllabus should explore inspirations from traditional and non-literate mode of counselling. Earlier, different forms of indigenous counselling practices in Nigeria were identified. It is the view of this writer that it is necessary to design one or two courses around these traditional forms of counselling and integrate them into counselling curriculums in Nigerian Universities.

The Nigeria Programme should not concentrate only on foreign theories imported from the Unites States of America, and Europe. It is worrisome that there is almost no effort made to integrate aspects of indigenous theories of vocational and career counselling in the Syllabuses of Guidance and Counselling in any Nigerian University. The importance of the multicultural context of Nigeria and the role this plays in determining individual's future career should not be forgotten.

Denga (1983) recognizes ethnicity and religion as two strong forces militating against effective and efficient functioning of counselling in Nigeria, and this, according to him is because most specialists fail to reckon with these factors in their work. Denga states further:

Counselling practice, however, does run into frequent clashes with African traditions and development goals typical of developing countries. In order to become fully acceptable at this initial stage, the guidance and counselling profession in Africa must tolerate some compromises and modifications from its original philosophy in the Western sense (Denga, 1983, pp. 115-123). 
He was of the strong opinion that modern counselling theories cannot be effective without considering the indigenous contexts in Nigeria. It is important to give his position some thought.

\section{- New syllabus of study and its implementation}

For the implementation, the updated syllabuses will need to combine relatively recent methods of teaching and organization (seminars, workshops, excursions, group work, power-point-presentations, among others). As stated earlier, quite a number of these methods are already being adopted. This however is by individual lecturers in courses scattered over different levels. In my view, there is a need to begin to systematically adopt these methods of impacting knowledge. To achieve this, it may be necessary to seek funds for facilities and equipment from both local funding agencies such as Tertiary Education Trust Fund (TETFund) and international foundations like the Ford Foundation and the German GTZ (now GIZ).

To further improve the academic programme of Guidance and Counselling, academic staff in Nigeria, as well as their students, needs more exposure to national and international exchange programme in form of workshops, conferences, in-service-trainings, etc. Towards achieving this, it may be necessary to deliberately explore the possibilities of international collaborations with Universities in Europe, North America, Australia and New Zealand as well as such Asian countries as Indian, China, Malaysia, Singapore, Japan and Thailand. Following such development, vocational and career counselling programmes in Nigerian Universities will become professionalized, with adequate opportunities provided for specialists to discharge their responsibilities fully and effectively, and for their students to acquire training that will prepare them adequately for the challenges their future job will pose to them and be able to compete internationally.

Finally, it is suggested that the following out-lined syllabus for the study programme in Nigerian Universities. The content and its structure have been inspired by internationally recognized competence profile of Vocational and Career Counselling, in different parts of the world.

\section{CONCLUSION}

What this paper has done is to undertake a scientific analysis of a representative programme of study in Guidance and Counselling in 


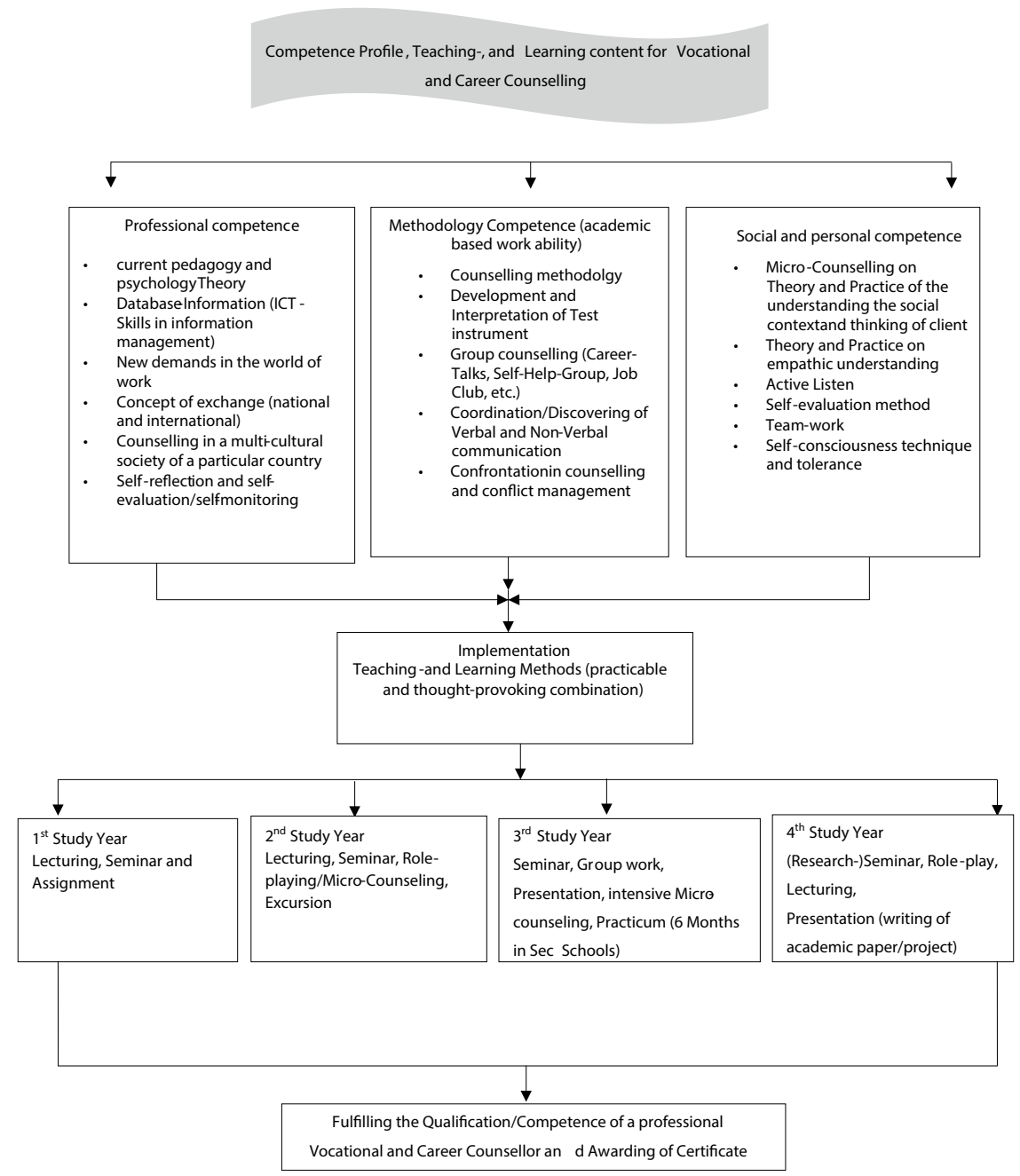

Figure 2. Suggested Model for the Study Programme in Vocational and Career Counselling in Nigeria Universities

Source: Raji, 2017, p. 1627.

a Nigerian University, comparing it with what obtains in the German HdBA at the present moment. The aim is to ascertain the adequacies or otherwise of the programme being run in Nigeria. Compared with the German model which the paper takes as the benchmark, the 
Nigerian programme ranks low. The teaching methods are adjudged to be outdated, the practical components of the programme considered as insufficient and the facilities available for staff and students' work inadequate. The implication of this for higher education is that the Nigerian programme may not be able to compete favourably when set against global standards.

But there is a major limitation to the study, and this lies in the fact that the data set against the chosen benchmark was drawn from only one Nigerian University, that is the University of Ibadan. The fact may cause a question mark to be thrown against the attempt at generalising the conclusions drawn from the findings for the entirety of the Nigerian system. In future studies therefore, I intend to draw my data from more representative Nigerian Universities, and/or, better still, from representative African Universities - say, Nigeria, Kenya and South Africa. Clearly, in a world that is ceaselessly getting globalised, it is important for University programmes in the developing world to be able to compete favourably when set against their equivalents in more advanced contexts.

\section{REFERENCES}

Agbaje, A. A., \& Agbaje A. O. (2014). Understanding problems of vocational counselling information seeking behaviour in the modern Nigeria. Journal of Humanities and Social Science, 19(5), Ver. II, 1.

Aluede, O. (2008). A roadmap to the professionalization of guidance and counselling in Nigeria. Edo Journal of Counselling, 1(1) 1-15, http://www.ajol.info/ index.php/ejc/issue/view/7041; http://www.ajol.info/index.php/ejc/article/ viewFile/52379/40996 (access: $20^{\text {th }}$ January 2017).

Aluede, O. \& Ikechukwu, B. N. Q. (2001). School counsellor's roles in minimising adolescents' attrition from schools. Orientación y socied, 2001/2002, 3, 1-9.

Amtsblatt der Europäischen Union (2008). Entschließung des Rates über eine erneuerte europäische Agenda für die Erwachsenenbildung, https://eur-lex.europa. eu/legal-content/DE/TXT/PDF/?uri=CELEX:32011G1220(01)\&from=EN (access: $20^{\text {th }}$ January 2017).

CEDEFOP (Hrsg.) (2004). Strategien zur Bildungs- und Berufsberatung: Trends, Herausforderungen und Herangehensweisen in Europa. Ein Synthesebericht des Cedefop von R.G. Sultana. Cedefop panorama series; 102, Luxemburg: Amt für amtliche Veröffentlichungen der Europäischen Gemeinschaften. 
Denga, D. I. (1983). The state of counselling in Nigeria. International Journal for the Advancement of Counselling, 6(2), 115-123.

Department of Guidance \& Counselling (2006). Undergraduate academic programme handbook. Ibadan, Nigeria: University of Ibadan.

Department of Guidance \& Counselling (2006). Reviewed syllabus of study. Ibadan, Nigeria: University of Ibadan.

Buschbeck, Chr., Geller, J. \& Koch, H.-P. (2007). Berufsbild „Berufsberater/Berufsberaterin“ Weiterentwicklung und Überarbeitung: Beschlussfassung der Mitgliederversammlung November 2007. Deutscher Verband für Bildungsund Berufsberatung e.V. (dvb), Bundesvorstand. www.dvb-fachverband.de (access: 20 $0^{\text {th }}$ January 2017).

Ertelt, B. J. (2007). Berufsberatung und beraterische Kompetenzen in europäischer Dimension. In: U. Sickendiek, F. Nestmann, F. Engel \& V. Bamler (Hrsg.). Beratung in Bildung, Beruf und Beschäftigung. Tübingen: dgvt-Verlag, $117-138$.

Ertelt, B. J. (2010). Akademische Aussbildungsgänge für Berufsberatung in Deutschland, 1-3, http://mevoc.net/publik/Berufsausbildung\%20Deutschland.pdf (access: $12^{\text {th }}$ September 2017).

Ertelt, B. J. \& Schulz, W. E. (2015). Handbuch Beratungskompetenz: Mit Übungen zur Entwicklung von Beratungsfertigkeiten in Bildung und Beruf. SpringerGabler, 3. Auflage.

Federal Republic of Nigeria (2013). National policy on education (3 $3^{\text {rd }}$ ed.). Vgl. National Policy on Education, Federal Republic of Nigeria 2013, Paragraph $9, \S 89$, S. $41, \S \mathrm{I}$.

Hochschule der Bundesagentur für Arbeit (HdBA) (2010). Studienführer, Mannheim. Hochschule der Bundesagentur für Arbeit (HdBA) (2011). Selbstbericht zur Programm-Reakkreditierung der beiden Bachelorstudiengänge der Hochschule der Bundesagentur für Arbeit (HdBA), Mannheim/Schwerin.

Ivey, A. E., D’Andrea, M., Bradford-Ivey, M., \& Simek-Morgan, L. (2002). Theories of Counseling and Psychotherapy: A Multicultural Perspective $\left(5^{\text {th }} \mathrm{ed}.\right)$. Boston, London, Toronto, Sydney, Tokyo, Singapore: Allyn\& Bacon.

Makinde, I. O. (1998). Historical foundation of counselling in Africa. Journal of Negro Education, 47(3) 303-311.

OECD (Hrsg.) (2004). Bildungs- und Berufsberatung. Bessere Verzahnung mit der öffentlichen Politik. Paris. Kurzfassung Bildungs- und Berufsberatung: Bessere Verzahnung mit der öffentlichen Politik. Overview Career Guidance and Public Policy: Bridging the Gap German translation, http://www.oecd. org/dataoecd/35/53/30499492.pdf (access: $28^{\text {th }}$ August 2011). 
Oladele, J. O. (2007). Guidance and Counselling: A Functional Approach, Focus on the 6-3-3-4 Educational System (4 ${ }^{\text {th }}$ ed.). Lagos, Nigeria: Johns-Lad Publishers Limited.

Olatunbosun, J. B. (2009). Examination Malpractice in Secondary Schools in Nigeria: What Sustains It? http://ozelacademy.com/EJESV1N3_1.pdf (access: $20^{\text {th }}$ January 2017).

Onoyase, D. \& Onoyase, A. (2009). Relationship between personality types and carrier choice of secondary school students in Federal Government Colleges in Nigeria. Journal of Anthropologist, 11(2) 109-115, http://www.krepublishers. com/02-Journals/T-Anth/Anth-11-0-000-09-Web/Anth-11-2-001-09-Abst-PDF/ Anth-11-2-109-09-487-Onoyase-D/Anth-11-2-109-09-487-Onoyase-D-Tt.pdf (access: 20 ${ }^{\text {th }}$ January 2017).

Organisation für wirtschaftliche Zusammenarbeit und Entwicklung (OECD) / Europäische Kommission (2004). Berufsberatung - Ein Handbuch für Politisch Verantwortliche. Luxemburg: Amt für amtliche Veröffentlichungen der Europäischen Gemeinschaften.

Owoyele, J. W. \& Toyobo, O. M. (2008). Parental will, peer pressure, academic ability and school subjects by students in senior secondary schools. Medwell Journals. The Social Sciences, 3(8), 583-586, http://docsdrive.com/pdfs/ medwelljournals/sscience/2008/583-586.pdf (access: 20 $0^{\text {th }}$ January 2017).

Raji, M. N. (2007). Möglichkeiten der Unterstützung der Berufswahl Jugendlicher an der Universität Ibadan, Bundesland Oyo, Nigeria-Potentialanalyse und Entwicklung einer Konzeption. Masterarbeit: Technische Universität Dresden.

Raji, M. N. (2012). Professionalisierung von Bildungs- und Berufsberatung in Nigeria. Analyse der Nationalen und Internationalen Theorie Begründeten Konzeptenwicklung und der Vernetzung der Akteure, http://www.qucosa. de/fileadmin/data/qucosa/documents/9756/RajiThesisGesamt.pdf (access: $20^{\text {th }}$ January 2017).

Raji, M. N. (2014). Situational analysis of Vocational/Technical Education and Training (TVET) programs in the State of Osun (Being Report submitted to Osun State Government).

Raji, M. N. (2015). Report of situation analysis of nine Technical Colleges in the State of Osun submitted to the Government, State of Osun, Nigeria.

Raji, M. N. (2017). The Processes of professionalizing vocational and career counselling in Nigeria. Africa Journal of Cross-Cultural Psychology and Sports Facilitation (AJCPSF), 19, ISSN 1119-7056, 1627.

Schiersmann, Chr. \& Weber, P. (eds.) (2013). Beratung in Bildung, Beruf und Beschäftigung. Eckpunkte und Erprobung eines Integrierten Qualitätskonzepts. Bielefeld: Bertelsmann Verlag. 
Weiß, R. (2009). Guteberatungwillgelerntsein. Berufsbildung in Wissenschaft und Praxis (BWP), (4), 3-4, http://www.bibb.de/dokumente/pdf/a1_bwp_04_2009_ kommentar.pdf (access: 20 $0^{\text {th }}$ January 2017).

Enech, G. A. \& Oko, I. E. (2008). The national policy on education: The crisis and challenges to counsellors. In: Conference Proceeding for the $33^{\text {rd }}$ Annual National Conference of the Counselling Association of Nigeria, CASSON. 